\title{
"Principal - Agent" Problem in the Context of the Economic Survival ${ }^{\#}$
}

\author{
Jiří Hlaváček*-Michal Hlaváček**
}

Generally the "Principal - Agent" problem could be characterised as delegated decision - situation, where one economic subject, referred as principal, strikes a bargain (contract) with the second subject (agent) while there is expectation that the agent would decide for the benefit of the principal.

From its first formulation [see Ross, A. (1973), Mirrlees, J. A. (1974), Jensen, M. C. Meckling, W. H. (1976)] this part of microeconomic theory develops dynamically [for example Bolton P., Dewatripont M (2005), Gintis, H. (2000), Vives, X. (2000), Denis, D. K., McConnell, J. J. (2003), Solomon, J. - Solomon, A. (2004) and many other important papers including contributions of several Nobel price winners: see Jonáš (1994), Janda, K. (2006)]. Principal - agent principle is widely applied in many other economic and even non-economic areas, for example in macroeconomics and economic policy [Epstein, G. A., Gintis, H. M. (1995)], in institutional economy [Furubotn, E. G., Richter, R. (1997), Spulber, D. F. (1999)], in political sciences [relation of electors and politicians in v Keech, W. R. (1994), constitution theory in Laffont, J. J. (2000), conflict problems in Arrow, K. J. (1995)] , in sociology [see Cook, K. S., ed. (2001)] or in theory of law [Polinsky, A. M., Shavell, S. (2000), Adler, M. D., Posner, E. A. (2001)]. In the Czech Republic these models were applied for example for the description of the banking sector [Frait, J.(2002)], changes of the ownership structure [see Kapička, M. (2000), Marek, P. (2004)], changes in the credit market [Janda, K. (2003), (2005)], legislative environment [Bortel, L. (2004)], health service [Krabec, T. (2005)] and insurance sector [Daňhel, J., (2002)].

Our contribution stays thoroughly within microeconomic level. We consider narrower approach which discusses only those common activities of the principal and the agent whose are not unrepeated trade. We also restrict our analysis only to situations where there is just one principal. By this assumption we could avoid the problem of conflicting interests of different principals - if the agent has more than one principal, each with different interests and different relation towards risk, than even if he wants to act in best interest of all of those principals, this is not possible to achieve.

The microeconomic problem "Principal - Agent" could for example refer to relation between:

- owner and manager,

- employer and employee,

\# The article is processed as an output of a research plan Integrace české ekonomiky do EU a její rozvoj registered by the Ministry of Education, Youth and Sports under the registration number MSM 0021620841.

* Prof. RNDr. Jiří Hlaváček, CSc. - professor, Institute of Economic Studies, Faculty of Social Sciences, Charles University, Prague, Smetanovo nábřeží 6, 11000 Praha 1, Czech Republic <jihlava@fsv.cuni..cz>; research fellow; Department of Econometrics, Institute of Information Theory and Automation of the Academy of Sciences of the Czech republic, Pod Vodárenskou věží 4, 18208 Praha 8.

** PhDr. Michal Hlaváček, Ph.D. - assistant, Institute of Economic Studies, Faculty of Social Sciences, Charles University, Prague, Smetanovo nábřreži 6, 11000 Praha 1, Czech Republic; <hlavacekm@fsv.cuni..cz>; adviser to the Board, Czech National Bank, Na Př́kopě 864/28, 11000 Praha 1; <michal.hlavacek@cnb.cz>. 
- creditor and debtor,

- firms where one firm orders commission to second firm (as subcontractor or within co-operation),

- landowner and tenant,

- litigant and its counsellor,

- investor and its portfolio manager,

- managing centre and subsidiary division within one company or in centrally planed economy,

- banking supervision and regulated bank,

- risk averse insured and risk neutral supplier of insurance,

- customer (for example trade chain) and supplier of some goods.

\section{"Principal - Agent" model}

Interaction between the principal and the agent could be described and modelled in following way: Let us suppose that the agent decides about his decision variable $e$ while this selection determines result $x=x(e, \theta)$, where $\theta$ is a random variable. Its probability distribution reflecting hidden information.

If the principal is fully informed about possible alternative decisions of the agent and about their implications, he can force the agent to make decision, which is optimal from the principal point of view. If there is uncertainty in the decision making (what is usual in the real economy), the agent usually has information superiority (so called hidden information), for example about available technology. Common characteristics of the "Principal Agent" situations is the endeavour of the principal to prevent the agent from abuse of this information superiority for agent's benefit and thus to principal's detriment.

Nevertheless, the principal knows that this hidden information $\theta$ is known to the agent but he can not get it from him. The agent makes his decision with knowledge about the value of $\theta$, while the principal could not follow neither $e$ nor $\theta$. The principal thus could try to convince the agent to display true value of variable $\theta$.

\section{Adverse selection}

If for example an insured knows his risks contrary to the insurance company, this could lead to so called adverse selection [firstly Rotchild, M., Stiglitz, J. E. (1976)]: there is tendency to use commercial insurance especially by those insured who are unprofitable from the point of view of the insurance company (in the sense of economic profit). This is also caused by the fact that the customers (agents) - in distinction from the insurance company - have information about the probability of their accident. When the price of insurance is the same for all customers, the insurance contract is most attractive for the riskiest customers, while the minimally risky ones are dissuaded from the contract by the mean price. Thus the insured are more risky compared with the average population. This is not re- 
lated only with the insurance market - many new customers of marriage agencies recognised that the supply by these agencies is worse than what it would correspond to the average population characteristics. Generally the adverse selection could be characterised as a situation in which the participation of the "undesirable" (from the point of view of the principal) customers in voluntary exchange is more likely.

For simplicity ${ }^{1}$ we will use the same income of $y_{i}=y$ for all agents $(i=1, \ldots, n)$. All agents are considered to be risk neutral with identical utility function $v_{i}(y)=y$. Moreover those agents face the identical loss $L_{i}=L$. The size of the loss $L$ is here (contrary to the model of moral hazard which is discussed in the next paragraph) an exogenous variable which could not be affected by the agent. We also assume that among the customers there are

- $(1-\gamma) \cdot n$ highly risky individuals whose have high probability of insured accident $\pi_{h}$,

- $\gamma \cdot n$ of less risky individuals with low probability of insured accidents $\pi_{b}$, while $\pi_{l}<\pi_{h}$.

Let us consider that the principal (insurance company) is risk neutral and that he knows the shape of the agent's utility function $v(y)=y$, his initial level of income $y$, the level of impending loss $L$, the share of less risky customers $\gamma \in(0 ; 1)$ and the probabilities of the insured accident of both types of the customers $\pi_{h}, \pi_{l}$, but he is not able to ex ante recognise the type of customer. This disables the principal to charge the highly risky insured with premium insurance of $p_{h}=\pi_{h} \cdot L$ to the highly risky insured and $p_{l}=\pi_{l} \cdot L$ to the less risky insured with $p_{l}=\pi_{l} \cdot L$; this insurance would correspond to the expected loss in the situation of the perfect information and would be Pareto effective for all the participating subjects.

Moreover, if the insurance company would charge "halfway" premium insurance given by the weighted average of the optimal premium insurance for highly and less risky individuals, while the weights are given by share of highly risky and the less risky agents (thus the insurance premium of $p=\gamma \cdot p_{l}+(1-\gamma) \cdot p_{h}$ ), it could be sure that only the highly risky agents would participate in the insurance and that it will create loss. This is true for every so called pooled (same for all agents) contract. Pooled contract could not be competitively equilibristic - in the competitive equilibrium the insurance company does not neither generate loss nor loses its customers due to competition with other insurance companies. Thus the expected value of profit for the randomly chosen customer has to be equal to zero. Competitive equilibrium thus has to generate zero profit which could not be true for any pooled contract.

The insurance company has to offer two different (so called "separating") insurance contracts by such way, which would "unmask" the agent. These insurance contracts will not differentiate only by their insurance premium, but also by the level coinsurance by the agent in case of eventual damage. The risky customer will incline towards the contract with the lower coinsurance and thus with the higher insurance premium.

Let us characterise these two insurance contracts by binary vectors $\left(p_{l}, q_{l}\right)$ (the contract designed for the less risky client) and $\left(p_{h}, q_{h}\right)$ (the contract designed for the highly risky client). The first component of the vector describing the insurance contract represents insurance premium and the second component represents the remittance transferred to the

1 The description of the model variables follows Gravelle and Rees (1992, chapter 22B). 
insured in the case of the occurrence of insured accident. We will mark the utility of the agent connected with the contract $(p, q)$ as $V(p, q)$.

For the insurance company it is necessary that the customers chose the contracts whose are designed for them. To ensure this the so called self-selection contract (condition) has to be fulfilled:

$$
\left[V_{h}\left(p_{h}, q_{h}\right) \geq V_{h}\left(p_{l}, q_{l}\right)\right] \&\left[V_{l}\left(p_{l}, q_{l}\right) \geq\left(V_{l}\left(p_{h}, q_{h}\right)\right] .\right.
$$

Second from those conditions could be omitted as inactive while if the less risky agent would chose this "stricter" contract it would be profitable from the point of view of the insurance company; nevertheless the rational agent chooses the favourable contract $\left(p_{l}, q_{l}\right)$. The insurance company has to secure only against highly risky customers thus only the first formula is active:

$$
V_{h}\left(p_{h}, q_{h}\right) \geq V_{h}\left(p_{1}, q_{1}\right) \text {. }
$$

This formula should ensure that the risky subject would not accept the contract which is giving advantage to the less risky agents. The self-selection condition is here thus (given expected neutrality towards risk of the agents $v(y)=y$ ):

$\left(1-\pi_{h}\right) \cdot\left(y-p_{h}\right)+\pi_{h} \cdot\left(y-L+q_{h}-p_{h}\right) \geq\left(1-\pi_{h}\right) \cdot\left(y-p_{I}\right)+\pi_{h} \cdot\left(y-\mathrm{L}+q_{1}-p_{1}\right)$.

On the other hand the competition among insurance companies leads to supply of the best (from the point of view of highly risky the agent) contract with zero expected profit; otherwise the rival insurance company would take over its customers.

The expected utility of the principal that does not know the risk profile of its customer is

$\gamma \cdot\left[\left(1-\pi_{1}\right) \cdot\left(y-p_{1}\right)+\pi_{1} \cdot\left(y-L+q_{1}-p_{1}\right)\right]+(1-\gamma) \cdot\left[\left(1-\pi_{h}\right) \cdot\left(y-p_{h}\right)+\pi_{h} \cdot\left(y-L+q_{h}-p_{h}\right)\right] \cdot$

Maximisation of this function given the self selection condition results in separating contract for highly risky client of $\left(p_{h}, q_{h}\right)=\left(\pi_{h} \cdot q_{h}, L\right)$ which is the contract consistent with contract under full information - full protection for price equivalent to the expected damage. Optimal separating contract for the less risky agent has to have only partial coverage $\left(q_{l}<L\right)$ and its insurance premium is equal to the expected value of execution of the insurance contract $\left(p_{l}=\pi_{l} \cdot q_{l}\right)$.

However the existence of such competitive equilibrium is not assured. It depends on share of the less risky customers, $\gamma$. If it is higher than some trigger value $\gamma^{*}$, there is unifying equilibrium (where the insurance company offers one contract to all) with zero expected profit and this equilibrium squeezes out the separating contracts from market. Nevertheless, as it was discussed above, any pooled contract can not be equilibrium. Thus the competitive equilibrium does not exist at all in this case.

If $\gamma \in\left(0 ; \gamma^{*}\right)$ the existence of the competitive equilibrium could be assured by suitable separating contracts. However, even here this equilibrium is not Pareto optimal. In comparison with case with perfect information the insurance companies have the same utility (zero profit), the highly risky agents are not better off, but the less risky agents are in worse situation, thus the equilibrium could not be Pareto effective. Thus the competitive equilibrium either does not exist at all, or it is not Pareto effective. 


\section{Moral hazard}

In other basic "Principal - Agent" type of model, in so called moral hazard model [for the first time Mirrlees, J. A. (1975), Holmstrom, B. (1979)] the agent chooses his decision $e$ before he knows the value of the random variable $\theta$. The principal can not follow neither agents decision $e$, nor the realisation of the random variable $\theta$, but only result of activity of the agent $x$. In this case the principal does not have the possibility to force the agent to choose the decision $e$ which would be the best from the point of view of the principal. Thus the principal will enforce contract rewarding the agent according to the outcome $x$. This results in situation (similarly to the adverse selection model) where the competitive equilibrium either does not exist or is Pareto inefficient.

Let us describe the model in greater detail for case of one agent (and one principal this is the assumption used during this paper).

Let us assume that the principal is risk neutral and that he behaves under perfect competition assumption (thus he is satisfied with zero expected economic profit as he does not want to miss a contract). Contrary to previous model the expected loss is endogenous to the model and is affected by decision of the agent.

Let us consider that the agent (let say insured) can spend some cost $c$ of money units to decrease the probability of insured accident. Let us consider (contrary to the principal) that the agent disposes the information that

- if he does not spend any money (thus if $c=0$ ), the probability of the insured accident is $\pi_{0} \in(0,1)$,

- if he spends amount $c=c_{1}$, the probability of the insured accident is $\pi_{1} \in\left(0, \pi_{0}\right)$.

Similarly to the previous paragraph we will denote $p$ as insurance premium, $q$ as a level of coverage of loss by the insurance company in case of the insured accident (while of course it has to hold that $q<L$ ) and $y$ as initial level of income of insured. Expected income of the prudent agent, who has bought the insurance contract and spent the $\cos t c_{1}$ to the decrease the risk is:

$$
\left(1-\pi_{1}\right) \cdot\left(y-c_{1}-p\right)+\pi_{1} \cdot\left(y-c_{1}-p-L+q\right) .
$$

If the insurance companies would have the same information as the insured (i.e. if they could check whether the client really spent costs to decrease of the probability of the insured accident), the competitive market would lead (for proof see Gravelle, H. - Rees, R., 1992, chapter 22C) to the Pareto optimal contract with full coverage $(q=L)$ and with the insurance premium of $p_{0}=L \cdot \pi_{0}$ charged to the non-prudent and $p_{1}=L \cdot \pi_{1}$ charged to the prudent client. The expected profit of the insurance company would be zero.

If the insurance company is uninformed and credulous, it will offer the contract $\left(L \cdot \pi_{1}, L\right)$. For the client it is optimal to accept this contract and not to spend the costs to decrease of risk, thus $c=0$. The expected profit of the insurance company is negative in this case, the insurance company creates loses due to its naivety.

Uninformed but suspicious insurance company proceeds similarly as in "adverse selection" model - it would offer the insurance contract with partial coverage. The clients whose are less risk averse will not spend the costs for risk reduction and would accept the contract with full coverage and higher insurance premium. Contrary to this the clients with high risk aversion will spend these costs and would accept the contract with partial cove- 
rage (for proof see Gravelle, H. - Rees, R., 1992, chapter 22C). The expected profit of the insurance company is zero, which is the same as in situation of the perfect information of the insurance companies.

Contrary to the insurance companies the insured is worse off compared to the situation of the perfect information of the insurance companies - he has either lower coverage with same expected income, or lower expected income with full coverage. Similarly to the adverse selection model thus this equilibrium is not Pareto efficient.

Thus this model represents market failure of its kind. The state could endeavour to rectify this market failure by its tax policy, for example in the health insurance by higher taxes on cigarettes stimulating spending of the costs to decrease of the health risks (costs of anti nicotine addiction therapy) or in the area of the property insurance by the decrease of the indirect taxes on alarms or safety locks. This could lead to the improvement in the Pareto efficiency sense. The problem lies in the fact that the government would need a lot of information about the preferences and the budget constraints of the decision problem of the economic agents to set the optimal tax regime. However, if the principal does not have this information, most likely the state will not have it as well.

The common problem of the "moral hazard" and "adverse selection" models is thus the fact that it is impossible to reach Pareto efficient equilibrium of even impossible to reach contract beneficial for both sides. Thus even if the competitive equilibrium exists, it is not Pareto efficient.

For those conclusions the assumed decision criterion of the economic subjects in the form of the maximisation of the expected income is crucial. In paragraph 3 we will show that the generalisation of the decision criterion of the agents to the maximisation of the probability of their survival together with survival of the agent (which is conditioned by survival of the principal) could under some conditions guarantee existence of the competitive equilibrium even in cases, where those would not be feasible if we use the criterion of maximisation of the expected utility from expected income.

We will show, that the change of the decision criterion to maximisation of the survival of the agents enables us to model some situations characterised by double criterion for one decision problem and the imperfect information of one of the subjects, while the interests of the principal and the agent could be at least partially jointly satisfied. In the next paragraph we list some basic assumptions of the generalised microeconomic theory which assumes that the probability of the economic survival (which is maximised by the economic subjects) is proportional to the relative reserve to the threshold under which the subject ceases with hundred percent probability. This could be described by Pareto probability distribution. This is the original theoretical concept developed by the authors of this paper.

\section{Generalised microeconomics: maximisation of the probability of the economic survival}

Maximisation of the probability of survival is the natural criterion of the economic subject. This criterion has to be followed (at least implicitly) by any economic subject behaving in some economic environment with the risk of downfall. Behaviour leading to maximal probability of the survival is ex definitione the basic characteristics of the subjects surviving in risky environment. 
Maximisation of the own economic survival is the generalisation of the general economic paradigm of the homo oeconomicus. If the economic subject behaves within environment characterised by the relations between the subjects similar to the perfect competition model, it is possible to capture all of his economic decisions by the maximisation of his economic result, thus by difference between the income and the costs. In this case the maximisation of the economic survival is represented by the maximisation of the profit. The homo oeconomicus subject is thus the special case of the economic subject behaving under maximisation of his economic survival criterion.

The real economic environment is much more complicated compared to the perfect competition model. Prices are not parametric (exogenously given) from the point of view of the economic subjects, the economic activities of the different economic subjects are interrelated, there are costs connected with the entry and the exit to the industry, there are the transaction costs (for example connected with establishment or with termination of the economic contract between two subjects), some subjects could intentionally affect the economy and the economic survival of the other subjects, the economic downfall of one subject could threaten survival of the other subjects etc.. In such environment it is not possible to limit ourselves on the criterion of "anonymous" profit maximisation without losing part of information capability. This led us to formation of this generalised microeconomics.

Our generalised microeconomics ${ }^{2}$ is able to model economic activities whose are outside the reach of the standard microeconomics based on the homo oeconomicus paradigm. It works with cardinal utility function and with deterministic model of the relation of the economic subject towards risk (Hlaváček, J. - Hlaváček, M., 2004a). Among other we have used this concept to describe altruism (Hlaváček, J. - Hlaváček, M., 2004c, 2004d) and donatorship (Hlaváček, J. - Hlaváček, M., 2002c, 2004b), positive externality (Hlaváček, M., 2003), supply side in the college education (Hlaváček, J., 2005) and in the sectors with unremitting returns to scale (Hlaváček, J. - Hlaváček, M., 2002a), demand function for insurance (Hlaváček, J. - Hlaváček, M., 2006), we have empirically analysed the process of the downfall of the firms in the Czech economy during the end of 1990ties (Hlaváček, J. - Hlaváček, M., 2002b). Generalised microeconomics comprehends also the microeconomic theory of the homo se assecurans as the special case used for the description of the ineffective behaviour of the firm in the centrally planed economy (Hlaváček, J., 1987; Hlaváček, M., 1990).

The basic assumption of the generalised microeconomics is the assumption that the behaviour of the economic subject in the existentially risky environment could be described by the optimisation model, in which the probability of the survival stands for the utility function $^{3}$. This probability is dependant on the level of the critical variable. This variable could be (but does not have to $\mathrm{be}^{4}$ ) the income of the modelled subject.

We consider the following assumption about this probability:

- it is equal to zero for income equal to some threshold, respectively with income below this threshold,

- it approaches one as the critical variable (income) grows to infinity,

2 For foundations of this theory and the utility function used in it see Hlaváček, J. et al. (1999), Hlaváček, J. (2000).

3 This implicitly means that the agent in our model is risk averse.

4 For example when we modelled the behaviour of the universities threatened by the loss of the accreditation caused by departure of the lecturers and by low demand from the side of students (or candidates) the crucial variables were the salary of the lecturers and the tuition. See Hlaváček, J. (2005). 
- it is bigger if the relative reserve of the critical variable grows in relation to the threshold of the definite downfall.

These a ssumptions are fulfilled by the Pareto distribution of the first degree. Let us denote $y$ as the value of the critical variable whose decrease under the threshold $b>0$ would lead to certain downfall. Distribution function (probability of the downfall for the critical variable equal to $y$ ) is thus for this distribution ${ }^{5}$ :

$$
\begin{array}{lll}
F(y)=(y-b) / y & \text { for } & y \geq b, \\
F(y)=0 & \text { for } & y<b
\end{array}
$$

Corresponding probability density function is

$$
\begin{array}{lll}
f(y)=b / y^{2} & \text { for } & y \geq b \\
f(y)=0 & \text { for } & y<b
\end{array}
$$

Fig. 1: Pareto distribution of the first degree for the threshold of the definite downfall of $b=1$ : distribution function $F(y)$, probability density function $f(y)$

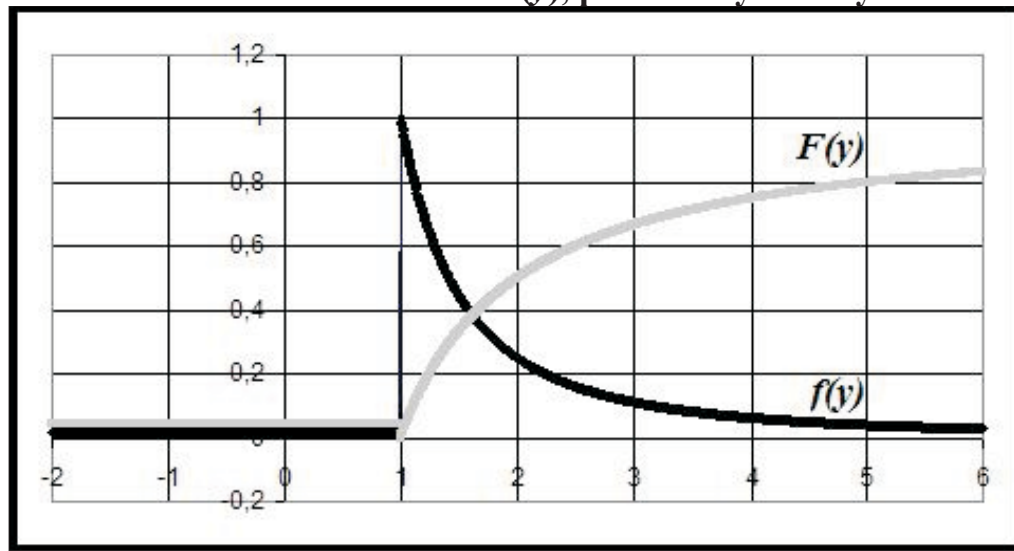

Pareto distribution of the first degree has median equal to double of the border of the unavoidable downfall (on graph $y$ equal to 2 ), the expected value and variance are infinite. Probability of survival is here ex definitione proportional to relative reserve, thus the probability of avoiding downfall due to low level of critical variable y is for example for $y=1.6$ triple relative to $y=1.2$ : relative reserve is in the first case $60 \%$, in second $20 \%$.

\section{Threatening of the agent by downfall of the principal}

If the economic survival of the agent depends on the survival of the principal than there is an overlap of interests of the principal and the agent - the overly "defrauded" principal could suffer economically and even go bust. The agent thus follows (but does not maximise) interests of the principal even in his own interest.

5 General Pareto distribution has distribution function of $F(x)=1-(b / x) \cdot a$ for $x>b$, where $a$ denotes degree of the distribution. 
In this paragraph we assume, that the survival of the principal is a necessary condition of the survival of an agent. This does not hold the opposite way round - the principal survives even after eventual downfall of the agent ${ }^{6}$.

Let us consider that the agent maximises his probability of economic survival. For the principals we assume - similarly to paragraph 2 - their endeavour to achieve at least zero expected income connected with the contract. This is a condition of the competitive equilibrium, whose would take effect in case of perfect information.

However, similarly to the previous paragraphs we consider the information asymmetry. The agent knows his probability of the insured accident, the principal does not.

\section{Adverse selection in the context of the probability of the survival maximisation concept}

The principal supplies the agents the coverage of the risk of insurance accident for some pecuniary interest (price of the contract $p$ ). He differentiates between two types of the agents - the highly risky and the less risky client.

We will label by $y_{p}$ the starting level of the income of the principal, $y_{a}$ the starting level of the income of the agent, $L$ the level of the eventuate loss, $\gamma \in(0 ; 1)$ the share of the highly risky agents with high probability of the accident $\pi_{h}$, probability of the accident of the less risky agents $\pi_{l}$. while $\pi_{l}<\pi_{h}$. We will denote the border of unavoidable downfall of the agent as $b_{a}$, the same threshold for the principal is denoted as $b_{p}$.

Same as above we will consider that the principal is not able recognise ex ante the kind of the agent he only knows the share of the highly risky agents $\gamma \in(0 ; 1)$. If the principal offers polling contract with price $p$ and with full coverage, his expected income coming from the contract is:

$$
y_{p}=\gamma \cdot\left(y_{p}-\pi_{h} \cdot L+p\right)+(1-\gamma) \cdot\left(y_{p}-\pi_{1} \cdot L+p\right) .
$$

The probability of the principal's survival is

$$
v_{p}(p)=\frac{\gamma \cdot\left(y_{p}-b_{p}-\pi_{h} \cdot L+p\right)}{b_{p}}+\frac{(1-\gamma) \cdot\left(y_{p}-b_{p}-\pi_{1} \cdot L+p\right)}{b_{p}} \text {. }
$$

We assume impossibility of the independent survival of the agent - if the principal ceases, the agent ceases as well:

$$
v_{a}(p)=\frac{v_{p}(p) \cdot\left(y_{a}-p-b_{a}\right)}{b_{a}} .
$$

The agent maximising probability of parallel survival of both subjects does not prefer neither extreme decrease nor extreme increase of the price of the contract because:

$$
\lim _{p \rightarrow \infty} v_{a}(p)=0, \quad \lim _{p \rightarrow 0} v_{a}(p)=0 .
$$

Increase to the price of contract $p$ increases first and decreases second multiplicand in (8). The agent thus prefers price $p^{*}$ for which it does hold

6 Used methodology enables us to model also situations when the survival on the principal depends on (or even could be conditioned) by the survival of the agent. 


$$
\frac{v_{p}\left(p^{*}\right)}{v_{p}^{\prime}\left(p^{*}\right)}+p^{*}=b_{p} \cdot v_{p}\left(p^{*}\right)+p^{*}=y_{a}-b_{a} .
$$

It is substantial that both the highly risky and the less risky agents valuate the situation by the same way. Both are fully ensured against the accident, thus they have the same second multiplicand in (8). The possible accident decreases the probability of their survival only in consequence of decrease of the probability of the survival of the principal. This probability decreases by $L / b_{p}$ percentage points from level $\left(y_{p}-b_{p}+p\right) / b_{p}$ to $\left(y_{p}-b_{p}-L+\right.$ p) $/ b_{p}$. The less risky agents do not leave system more than the highly risky agents.

This means that if the survival of the agent is contingent on the survival of the principal than the problem of the adverse selection does not exist for subject maximising probability of their economic survival.

There is even in some sense opposite tendency. In paper Hlaváček, J., Hlaváček, M. (2006) we showed that the subjects with very low income do not show demand for insurance services, when the payment of the insurance premium increases probability of the economic downfall even if the insurance accident does not occur. By this the increase of the insurance premium leads to increase of the "seriousness" of the insured over the average of the population (and does not decrease this "seriousness" below the average population as in the standard adverse selection model). This is true despite of the insurance is not advantageous not even for extremely well financially established while those have very low sensitivity on changes to the insurance premium.

If the insurance premium increases by $\Delta p$, the expected income of the principal increases also by $\Delta p$. The principal thus gets better when the price of the contract increases. Contrary to this the number of the surviving agents and the demand on the insurance market are decreasing on interval $\left(0 ; p^{*}\right)$ while they are "modestly" increasing or constant in interval $\left(p^{*} ;+\infty\right)$. This means that the equilibrium does not have to exist. This holds for the case when $S\left(p^{*}\right)<D$. If the equilibrium insurance premium exists, than it is uniquely determined. For this price the expected profit of the principal is equal to zero.

The principal offers full coverage for the insurance premium, which is for the less risky agent higher than it would be for the case of the full information. Despite of this is this price accepted by the agent - from the point of view of his economic survival even the less risky agent gats better under given conditions.

This is thus the possible existence of the competitive Pareto equilibrium: neither the principal, nor the less risky agents and first of all the highly risky agents do not get worse relative to the perfect information case.

The strong assumption (8) could be modified (we plan to do it in our next research) for example in that sense that in the case of downfall of the principal this fact only cancels out the coverage of the insured accident. Such change would of course lead to significant change to the results of the analysis. We nevertheless expect that the existence of the competitive Pareto equilibrium will not be excluded.

\section{Moral hazard in the context of the probability of the survival concept}

In the moral hazard model we consider again only two subjects - the principal and one agent. We assume probability of the insured accident $\pi$ as endogenous variable here, the agent can (but need not) spend the additional cost to decrease this probability. He will do so if it increases his probability of the economic survival. Let us denote the costs to decrease 
the risk as $c$. Original (not reduced) probability of accident $\pi(0)=\pi_{0}$ decreases after spending the cost $c>0$ to level $\pi(\mathrm{c})=\pi_{1} \in\left(0, \pi_{0}\right)$.

We again assume, that the agent can not exist independently - if the principal perishes, the agent perishes as well:

$$
v_{a}(c)=\left[\frac{(1-\pi(c)) \cdot\left(y_{a}-p-b_{a}\right)}{b_{a}}+\frac{\pi(c) \cdot\left(y_{a}-p-L-b_{a}\right)}{b_{a}}\right] \cdot v_{p}(c) .
$$

The principal similarly to the previous paragraph maximises expected income:

$y_{p}(c)=y_{p}-\pi(c) \cdot L+p$.

Probability of the economic survival of the principal is thus:

$$
v_{p}(c)=\frac{y_{p}-b_{p}-\pi(c) \cdot L+p}{b_{p}} .
$$

Spending the expenditure for probability of the accident decrease increases the probability of the principal's survival to:

$$
v_{p}(c)>v_{p}(0)=\frac{y_{p}-b_{p}-\pi(0) \cdot L+p}{b_{p}} \quad, \text { for } \mathrm{c}>0 .
$$

For the agent the first multiplicand in (11) decreases the second multiplicand increases, thus the influence of spending cost $c$ on the utility of the agent (i.e. his probability of survival) is given by the difference:

$$
\begin{aligned}
v_{a}(c)-v_{a}(0) & =\left[\frac{(1-\pi(c)) \cdot\left(y_{a}-p-b_{a}\right)}{b_{a}}+\frac{\pi(c) \cdot\left(y_{a}-p-L-b_{a}\right)}{b_{a}}\right] \cdot v_{p}(c)- \\
& -\left[\frac{(1-\pi(0)) \cdot\left(y_{a}-p-b_{a}\right)}{b_{a}}+\frac{\pi(0) \cdot\left(y_{a}-p-L-b_{a}\right)}{b_{a}}\right] \cdot v_{p}(0)= \\
& =\frac{y_{a}-p-b_{a}}{b_{a}} \cdot\left[(1-\pi(c)) \cdot v_{p}(c)-(1-\pi(0)) \cdot v_{p}(0)\right]+ \\
& +\frac{y_{a}-p-L-b_{a}}{b_{a}} \cdot\left(\pi(c) \cdot v_{p}(c)-\pi(0) \cdot v_{p}(0)\right) .
\end{aligned}
$$

The sign of difference $v_{a}(c)-v_{a}(0)$ is driven by the relation of the extent of the threat of the agent and of the principal. If the agent regards the principal as "perdurable" he would not spend the cost and transfers his risk fully on the shoulders of the principal. The agent would thus pay $v_{a}(c)-v_{a}(0)<0$. The more endangered is the principal in eyes of the agent, the bigger is the difference $v_{a}(c)-v_{a}(0)$. For the extremely threatened principal it certainly holds $v_{a}(c)-v_{a}(0)>0$. Thus there is some limit over which the agent at his own would not practice the moral hazard and over which he would spend the cost for the probability of the accident elimination in interest of both.

\section{Conclusions}

Analysis has demonstrated that in the economy with agents maximising probability of their survival, the problem of the information asymmetry surfaces relatively weaker (compared to the standard economic climate with the subjects maximising their expected 
profit). This is true both for the specific case of the adverse selection the moral hazard problems.

We have shown that the adverse selection problem disappears if the survival of the agent is conditioned by the survival of the principal. There is even opposite tendency in this case - the most risky agents do not enter the contract because the payment of the insurance premium increases their probability of the economic downfall even when the accident does no appear. Under these conditions the Pareto efficient pooled contract could exist. Similarly the moral hazard problem could disappear when we consider dependence of the agent's survival on the survival of the principal.

\section{References}

[1] ADLER, M. D. - POSNER, E. A., (eds.) (2001): Cost-benefit analysis: Legal, economic, and philosophical perspectives. Chicago, University of Chicago Press, 2001.

[2] ARROW, K. J. - MNOOKIN, R. H. - ROSS, L. - TVERSKY, A. WILSON, R. (eds.) (1995): Barriers to conflict resolution. New York, Norton, 1995.

[3] BOLTON, P. - DEWATRIPONT M (2005): Contract theory. Cambridge, MIT Press, 2005.

[4] BORTEL, T. (2004): Ekonomická analýza práva (Economic Analysis of Law). Politická ekonomie, 2004, Vol. 52, No. 1, pp. 91-102.

[5] COOK, K. S. (ed.) (2001): Trust in society. New York, Russell Sage Foundation, 2001

[6] DAŇHEL, J. (2002): K problému asymetrie informací v pojištovnictví (Observations regarding the Issue of Asymmetric Information in Insurance). Politická ekonomie, 2002, Vol. 50, No. 6, pp. 809-813.

[7] DENIS, D. K. - McCONNELL, J. J. (2003): International Corporate Governance. Journal of Financial and Quantitative Analysis, 2003, Vol. 38, No. 1, pp. 1-36.

[8] EPSTEIN, G. A. - GINTIS, H. M. (eds.) (1995): Macroeconomic policy after the conservative era: Studies in investment, saving and finance. Cambridge, Cambridge University Press, 1995.

[9] FRAIT, J. (2002): Morálni hazard a výstup z bankovniho sektoru (Moral Hazard and Orderly Bank Exit). Finance a úvěr, 2002, Vol. 52, No. 2, pp. 102-104.

[10] FURUBOTN, E. G. - RICHTER R. (1997): Institutions and economic theory: The contribution of the New Institutional Economics. (Economics, Cognition and Society). Ann Arbor, University of Michigan Press, 1997.

[11] GINTIS, H. (2000): Game Theory Evolving: A Problem - Centered Introduction to Modeling Strategic Interaction. Princeton, Princeton University Press, 2000.

[12] GRAVELLE, H. - REES R. (1992): Microeconomics. Amsterodam, North Holland, 1992.

[13] HLAVÁČEK, J. (1987): Homo se assecurans. Politická ekonomie, 1987, Vol. 34, No. 6, pp. 633-639. 
[14] HLAVÁČEK, J. (1990): Producers Criteria in a Centrally Planned Economy. In Quandt R.E - Tř́ska, D. (eds.): Optimal Decisions in Markets and Planned Economies. New York, Westview Press, 1990.

[15] HLAVÁČEK, J. - ČERNOUŠEK, M. - KABELE, J. - MEJSTŘÍK, M. (1999): Mikroekonomie sounáležitosti se společenstvím (Microeconomics of Co-existence with Society). Praha, Karolinum, 1999.

[16] HLAVÁČEK, J. (2000): Zobecněné mikroekonomické kriterium v tržní ekonomice (Generalized Principle of Firms Behavior in Market Economy). Politická ekonomie, 2000, Vol. 48, No. 4, pp. 515-529.

[17] HLAVÁČEK, J. (2005): Dynamický model soustavy univerzit (Dynamic Model of a System of Universities). Praha, Charles University, Faculty of Social Sciences Working paper No. 90, 2005.

[18] HLAVÁČEK, J. - HLAVÁČEK, M. (2002a): Optimum výrobce při stále rostoucich výnosech z rozsahu. (Producer's Optimum under Unremitting Increase of Returns to Scale). Politická ekonomie, 2002, Vol. 50, No. 5, pp. 689-698.

[19] HLAVÁČEK, J. - HLAVÁČEK, M. (2002b): Porovnání přeživajicích a zanikajicích podnikư v české ekonomice na konci 90. let, (A Comparative Study of Exiting and Surviving Firms in the Czech Economy in the Late 1990s). Finance a úvěr, 2002, Vol. 52, No. 2, pp. 502-514.

[20] HLAVÁČEK, J. - HLAVÁČEK, M. (2002c): Ekonomická racionalita donátora (kdo s důvěrou dává, dvakrát dává). (Economic Rationality of Donator (who Trustful Gives, Gives two Times). In Kabele, J. - Mlčoch, L. (eds.): Konsolidace vládnutí a podnikání v České republice a v Evropské unii: Umění vládnout, ekonomika, politika. Praha, Charles University, Matfyzpress 2002, pp. 258-268.

[21] HLAVÁČEK, J. - HLAVÁČEK, M. (2004a): Petrohradský paradox a kardinální funkce užitku (St. Petersburg's Paradox and Cardinal Utility Function). Politická ekonomie, 2004, Vol. 52, No. 1, pp. 48-60.

[22] HLAVÁČEK, J. - HLAVÁČEK, M.(2004b) Ekonomická iracionalita donátora plynoucí z nedi̊verry k př́jemci dotace (Economic Irrationality of the Donator Arising from his Low Confidence in Donation Recipient). Finance a úvěr, 2004, Vol. 54, No. 2, pp. 138-154.

[23] HLAVÁČEK, J. - HLAVÁČEK, M. (2004c): Cruel Altruism. Prague Economic Papers, 2004, Vol. 14, No. 2, pp. 363-374.

[24] HLAVÁČEK, J. - HLAVÁČEK, M.: (2004d): Models of Economically Rational Donator. Altruism can be cruel. In Kotábová, V. - Prázová, I. - Schneider, O. (eds.): Rozvoj české společnosti v Evropské unii. II, Ekonomie, Politologie. Praha, MatfyzPress, 2004, pp. 98-110.

[25] HLAVÁČEK, J. - HLAVÁČEK, M. (2006): Poptávková funkce na trhu s pojištěnim: porovnáni maximalizace paretovské pravděpodobnosti přežití s teorii EUT von-Neumanna a Morgensterna a s prospektovou teorií Kahnemana a Tverského, (Demand function in insurance industry: Comparison of maximization of Pareto's probability of survival with EUT theory and with the prospect theory of Kahneman and Tversky). Praha, Charles University, Faculty of Social Sciences, 2006. 
[26] HLAVÁČEK, M. (2003): Efektivnost pořizení a predáváni informace mezi privátními subjekty s pozitivně-externalitní vazbou (Efficiency of Information Transfer Between Agents Connected by Positive Externality). Praha, Charles University, Faculty of Social Sciences Working paper No. 32, 2003.

[27] HOLMSTROM, B. (1979): Moral Hazard and Observability. Bell Journal of Economics, 1979, Vol. 10, pp. 74-91.

[28] JANDA, K. (2003): Credit guarantees in a credit market with adverse selection. Prague Economic Papers, 2003, Vol. 12, No. 4, pp. 331-349.

[29] JANDA, K. (2005): The comparison of credit subsidies and guarantees in transition and post-transition economies. Ekonomický časopis, 2005, Vol. 53, No. 4, pp. 383-398.

[30] JANDA, K. (2006): Agency Theory Approach to the Contracting between Lender and Borrower. Acta Oeconomica Pragensia, 2006, Vol. 14, No. 3, pp. 32-45.

[31] JENSEN, M. C. - MECKLING, W. H. (1976): Theory of the Firm: Managerial Behavior, Agency Costs and Ownership Structure. Journal of Financial Economics, 1976, Vol. 3, No. 4, pp. 305-360.

[32] JENSEN, M. C. - SMITH, C. W. (1983): Stockholders, Manager, and Creditor Interests? Application of Agency Theory. Rochester, Managerial Economics Research Center, 1983, pp. 93-131.

[33] JONÁŠ, J. et.al. (1994): Oslava ekonomie (Celebration of Economics). Praha, Academia, 1994.

[34] KAPIČKA, M. (2000): Jaké jsou náklady a výnosy privatizace? (What are the costs and benefits of privatization?) Politická ekonomie, 2002, Vol. 48, No. 2 , pp. 201-214.

[35] KEECH, W. R. (1994): Economic politics: The costs of democracy. Cambridge, Cambridge University Press, 1994.

[36] KNOT, O. - VYCHODIL, O: What drives the optimal bankruptcy law design. Finance a úvěr, 2005, Vol. 55, No. 3-4, pp. 110-123.

[37] KRABEC, T. (2005): Institucionálni pohled na systémy zdravotni péče. (Health Care Systems -An Institutional View). Politická ekonomie, 2005, Vol. 53, No. 5, pp. 609-616.

[38] LAFFONT, J. J. (2000): Incentives and political economy. Oxford, Oxford University Press, 2000.

[39] MALÝ, M. - THEODOR, M. - PEKLO, J. (2002): Řizení a správa společností (Corporate Governance). Prague, Oeconomica, 2002.

[40] MAREK, P. (2004): Corporate governance and agency theory. Acta Oeconomica Pragensia, 2004, Vol. 12, No. 5, pp. 9-18.

[41] MARSDEN, D. (1999): A theory of employment systems: Micro-foundations of societal diversity. Oxford, Oxford University Press, 1999.

[42] MIRRLEES, J. A. (1974): Notes of welfare economics, information and uncertainty. In Balch, M. - McFadden, D - Wu, S. (eds.): Essays in Economic Behaviour under Uncertainty. Amsterodam, North Holland, 1974, pp. 243-261. 
[43] MIRRLEES, J. A. (1975): The Theory of Moral Hazard and unobservable behaviour. Oxford, Nuffield College, mimeo, 1975.

[44] ROSS, A. (1973): The Economic Theory of Agency: The Principal's Problems. American Economic Review, 1973, Vol. 63, No. 5, pp. 134-139.

[45] ROTCHILD, M. - STIGLITZ, J. E. (1976): Equilibrium in competitive insurance markets: an essay on the economics of imperfect information. Quarterly Journal of Economics, 1976, Vol. 90, No. 4, pp. 629-649.

[46] POLINSKY, A. M. - SHAVELL, S. (2000): The Economic Theory of Public Enforcement of Law. Journal of Economic Literature 38(1), 2000/1

[47] SOLOMON, J. - SOLOMON, A. (2004): Corporate Governance and Accountability. New York, John Wiley, 2004.

[48] SPULBER, D. F. (1999): Market microstructure: Intermediaries and the theory of the firm. Cambridge, Cambridge University Press, 1999.

[49] TURNOVEC, F. (2000): Who Are the Principals and Who Are the Agents? A Leontief - type Model of Ownership Structures. Finance a úvěr, 2000, Vol. 50, No. 11, pp. 648-650.

[50] VIVES, X. (ed.) (2000): Corporate governance: Theoretical and empirical perspectives. Cambridge, Cambridge University Press, 2000.

[51] WITTMAN, D. A. (1995): The myth of democratic failure: Why political institutions are efficient. American Politics and Political Economy series. Chicago, University of Chicago Press, 1995. 


\title{
Problém "principál - agent" při maximalizaci pravděpodobnosti ekonomického přežití
}

\author{
Jiř́ Hlaváček - Michal Hlaváček
}

\begin{abstract}
Abstrakt
Př́íspěvek analyzuje problémy v modelu asymetrické informace (modely „,principál agent") s tím, že u agentů se namísto standardní maximalizace očekávaného důchodu předpokládá maximalizace pravděpodobnosti ekonomického přežití. Soustřed'uje se na dva základní modely: nepř́iznivý výběr (,adverse selection“) a morální hazard. V obou případech je důsledek asymetrie informací slabší, popřípadě zcela mizí. Na rozdíl od standardního př́istupu v obou modelech může existovat konkurenční Pareto-optimální rovnováha při sdružujícím kontraktu s plným krytím př́ípadné havárie principálem.
\end{abstract}

Klíčová slova: morální hazard; nepř́iznivý výběr; pravděpodobnost přežití, Paretovo rozdělení pravděpodobnosti.

\section{"Principal - Agent" Problem in the Context of the Economic Survival}

\begin{abstract}
This paper analyses problems within the asymmetric information models (principal agent models) where we replace standard assumption of maximisation of expected income by maximisation of probability of economic survival. This paper concentrates on two basic models - adverse selection model and moral hazard model. In both cases the effect of asymmetry of information gets weaker or even disappears. Contrary to standard approach the competitive Pareto effective equilibrium could exists in both models with pooled contract with full coverage of possible accident by the principal.
\end{abstract}

Key words: moral hazard; adverse selection; probability of survival, Pareto distribution of probability.

JEL classification: D82 